\title{
Enzymatic desizing, bioscouring and enzymatic bleaching of cotton fabric with glucose oxidase
}

\section{Kiro Mojsov}

To cite this article: Kiro Mojsov (2019) Enzymatic desizing, bioscouring and enzymatic bleaching of cotton fabric with glucose oxidase, The Journal of The Textile Institute, 110:7, 1032-1041, DOI: 10.1080/00405000.2018.1535240

To link to this article: https://doi.org/10.1080/00405000.2018.1535240

Published online: 14 Nov 2018.

Submit your article to this journal $[\boldsymbol{T}$

Џلll Article views: 56

View Crossmark data [ᄌ 


\title{
Enzymatic desizing, bioscouring and enzymatic bleaching of cotton fabric with glucose oxidase
}

\author{
Kiro Mojsov \\ Faculty of Technology, "Goce Delcev" University, Stip, Macedonia
}

\begin{abstract}
The sized cotton fabric was enzymatically desized, scoured and bleached with an enzyme mixture of starch degrading enzymes, pectinases and glucose oxidases (GOxs) was added to generate hydrogen peroxide (HP). In this study, enzyme selection and process optimisation was made in order to increase the glucose content of the desizing liquor of a starch-sized cotton fabric. The highest glucose concentration of $4175 \mathrm{mg} / \mathrm{L}$ was measured in one-bath containing mixture of $\alpha$-amylase, amyloglucosidase and pectinase and GOx produced $758 \mathrm{mg} / \mathrm{L}$ peroxide. This combination was used in further bleaching processes. For bleaching, hydrogen peroxide was converted into peracetic acid (PAA) by incorporating the bleach activator tetraacetylethylenediamine (TAED). Whiteness values, water absorbency, polymerization degree and tenacity at maximum load were measured on pre-treated samples. The total organic carbon (TOC), chemical oxygen demand (COD), biological oxygen demand $\left(\mathrm{BOD}_{5}\right)$, the biological degradability $\left(\mathrm{BOD}_{5} / \mathrm{COD}\right)$ and the final $\mathrm{pH}$ values were measured on residual pre-treatment baths.
\end{abstract}

ARTICLE HISTORY

Received 6 October 2017 Accepted 6 October 2018

\section{KEYWORDS}

Cotton fabric; enzymes; bleach activator; peracetic acid; eco-friendly process

\section{Introduction}

Biotechnology as an ecological advantageous and moreover economical beneficial technology plays an increasingly important role in the industrial wet textile pretreatment and the finishing processes. The most established application of biotechnology in textiles has been in the field of enzymatic pretreatment (Buchert, Pere, Puolakka, \& Nousiainen, 2000; Csiszár et al., 2001). Therefore, in an enzymatic pretreatment, the textile substrate is less damaged when compared to a classical pretreatment. The most important natural cellulose fibre is cotton, whose use is constantly increasing. Natural cotton is highly hydrophobic and slightly coloured. To prepare the fibres for further treatment and use, pretreatment processes are needed. Among the pretreatments, desizing (removal of adhesive sizing material), scouring (removal of noncellulosic materials such as grease, wax, protein, hemi-cellulosic material, pectin, ash, dirt and oil from fabric to improve absorbency and whiteness of the textile material) and bleaching (imparting fixed standard whiteness to the fabric) are of special interest for cellulosic fabrics. Desizing, conventional scouring with sodium hydroxide and bleaching with hydrogen peroxide (HP) consume a lot of energy, water and chemicals and cause damage to fibers. Consequently, enzymatic pre-treatments of cellulose fabrics often save large amounts of raw materials, chemicals, energy and water.

Sizing materials (i.e. starch and waxes) protect the fabric against abrasive forces during weaving. About $75 \%$ of sizing agents used worldwide are starch and its derivatives
(Cavaco-Paulo \& Gübitz, 2003, p. 240). The size forms a protective film on the warp yarn, protruding fiber ends causing loom stops are minimized. Desizing is carried out to remove the adhesive material in order to render the fabric more accessible to the subsequent stages of the processing. Conventionally, it is carried out at a higher temperature in an acidic solution or with strong oxidizing agents in alkaline solution. In the past, hydrogen peroxide and sodium hydroxide were generally used as desizing agents. But this method was not economically and environmental-friendly. To decrease water and the chemicals consumption and in response to the environmental concerns, enzymatic desizing of cotton seems a practical alternative. However, starchbreaking enzymes (amylases) are preferred for desizing because of their high efficiency and specific action. Amylases are enzymes which hydrolyse starch molecules to give diverse products, including dextrins and smaller polymers composed of glucose units (Gupta, Gigras, Mohapatra, Goswami, \& Chauhan, 2003). Amylases bring about complete removal of the size without any harmful effects on the fabric.

Between 50 and $80 \%$ of chemical oxygen demand (COD) in effluents of textile finishing industries is caused by sizing agents, which contribute considerably to water pollution (Opwis, Knitel, Kele, \& Schollmeyer, 1999). Alternatively, the hydrogen peroxide could be produced in situ by enzymatic system glucose oxidase (GOx)/glucose (Schacht, Kesting, \& Schollmeyer, 1995). Therefore, the investigations were focused on the enzymatic generation of HP with GOx using glucose from desizing liquors as a substrate, which 